\begin{tabular}{|l|l|l||}
\hline \multicolumn{2}{|c|}{ PublisherInfo } \\
\hline \hline PublisherName & $:$ & BioMed Central \\
\hline \hline PublisherLocation & $:$ & London \\
\hline \hline PublisherImprintName & $:$ & BioMed Central \\
\hline \hline
\end{tabular}

\title{
Matrix modulation in monocytes
}

\begin{tabular}{|l|l|l||}
\hline \multicolumn{2}{|c|}{ ArticleInfo } \\
\hline \hline ArticleID & $:$ & 3955 \\
\hline \hline ArticleDOI & $:$ & $10.1186 /$ gb-spotlight-20010116-01 \\
\hline \hline ArticleCitationID & $:$ & spotlight-20010116-01 \\
\hline \hline ArticleSequenceNumber & $:$ & 26 \\
\hline \hline ArticleCategory & $:$ & Research news \\
\hline \hline ArticleFirstPage & $:$ & 1 \\
\hline \hline ArticleLastPage & $:$ & 2 \\
\hline \hline & & RegistrationDate : 2001-01-16 \\
ArticleHistory & $:$ & OnlineDate \\
\hline \hline ArticleCopyright & $:$ & BioMed Central Ltd2001-16 \\
\hline \hline ArticleGrants & $:$ & \\
\hline \hline ArticleContext & $:$ & 130592211 \\
\hline \hline
\end{tabular}




\section{Jonathan B Weitzman}

Email: jonathanweitzman@hotmail.com

The interactions of cells with the extracellular matrix (ECM) are critical for orchestrating immune and inflammatory responses. In the December Immunity, de Fougerolles et al. report a comprehensive analysis of gene expression profiles affected by the attachment of monocytes to fibronectin and other ECM components (Immunity 2000, 13:749-758). They used a quantitative, restriction enzyme-based profiling method, named GeneCalling, to examine the integrin-mediated induction of genes in the monocyte cell line THP-1. De Fougerolles et al. identified over 140 genes induced by matrix attachment, including several encoding secreted cytokine factors and cell surface receptors. ECM and growth factors synergistically activated many genes regulated by the NF-kappaB and Jak/STAT signalling pathways. Furthermore, different ECM substrates induced both distinct and overlapping gene sets. Matrix-induced genes are likely to play roles in extravasation, migration and phagocytosis by monocytic cells during the inflammatory response.

\section{References}

1. Adhesion receptors of the immune system.

2. Immunity, [http://www.immunity.com]

3. Gene expression analysis by transcript profiling coupled to a gene database query. 